and not worth transporting. This power station and one of the lines from Budapest were financed by an English loan on condition that a considerable part of the supplies were to be procured from English firms.

In Italy, the Valtelina railway was electrified with three-phase current in 1900, and this introduced the three-phase system into upper Italy. When it was decided to electrify the Bologna-Florence railway, direct current was used. Hence two systems, direct current and three-phase, are used in Italy. The bulk of the necessary electrical energy is obtained from water power stations, two thirds of which are railway owned and one third privately owned.

Mr. Kaan said he hoped that the recommendations of the Weir report for the railway electrification of Great Britain will be carried out, and expressed his great admiration for the way in which the Southern Railway Co. has electrified the London suburban lines and the lines to Brighton, Worthing, Seaford and Hastings.
In France it has been decided to use the grid system of the country to supply the railways. A high-tension grid $(60-220 \mathrm{kv}$.) has been constructed to connect the steam power stations of Paris with the water power stations of the Alps and Pyrenees. In order to afford employment, many lines are scheduled for electrification. It is interesting to notice that some of these are situated in the northern districts of the country, which are rich in coal.

In the United States, not quite one per cent of the 262,500 miles of lines have been electrified. The first long distance line was that connecting Baltimore, Washington and Annapolis. The factors that determined the introduction of electric traction were its greater efficiency in meeting competition and the substitution of water-power for coal.

Mr. Kaan also reviewed the position of electric traction in many other countries and in the British Dominions.

\title{
The Queen Mary and Timbers of the Empire
}

$\mathrm{T}$ HE latest addition to the Cunard fleet, and one of the largest ships now afloat, the Queen Mary, may be truly said to be an Empire ship. The decorations of her interior are largely of wood drawn from the forests of many parts of the Empire-India, the great Dominions and many Colonies.

Teak has long been used in ship construction, and some 1,000 tons of this fine timber has been utilised for decks and gangways, window frames and handrails and so forth. More interesting, perhaps, are some of the timbers which have been used in the magnificent panelling which forms so marked a feature of the interior fittings of the great saloons, smoking-rooms, lounges, corridors and state-rooms.

The builders, Messrs. John Brown and Co., Ltd., and their advisers have ransacked the Empire and indeed the world to collect examples of some of the richest timbers so far known to the trade; though this by no means indicates that the trades are yet aequainted with a tithe of the beautiful timbers existing in the moist tropical and mixed deciduous forests of the world. Apart from teak, the following woods amongst others have been used: laurel wood (Terminalia tomentosa), India; mahogany (Swietenia), British Honduras; cedar mahogany (Guarea cedrata or Thompsonii), Nigeria and Gold Coast; pommele mahogany (Entandrophragma?), Nigeria; Sapele (Entandrophragma cylindricum), British and French West Africa; lemon wood (Xymalos monospora), Southern Rhodesia and South Africa (or, Calycophyllum candidissum, Cuba); tiger oak, said to be Machaerium Schomburghii, Guianas ; Macassar ebony (Diospyros macassar and Diospyros sp.), Celebes; Amboyna (Pterocarpus sp.), Moluccas; Makoré (Mimusops Heckeli) and Avodiré (Turreanthus africana), Ivory Coast; Satinee, or Satiné rubane and Satiné rouge (Brosimum paraense), French Guiana (or, Satiné jaune, Zanthoxylum flavum, French West Indies); Peroba (Aspidosperma polyneuron or Paratecoma peroba, syn. Tecoma peroba), Brazil; oak nut, possibly nut oak (Macadamia ternifolia) and Australian walnut (Endiandra palmerstonii), Australia; Oregon myrtle (Acer macro- phyllum), United States of America; Masur birch (Betula), figured birch from Finland, North Russia and elsewhere; grey maple, stained maple and sycamore (Acer), and olive ash, figured wood (Fraxinus excelsior); walnut (Juglans regia) and beech (Fagus sylvatica), England and Europe. Also Queensland maple and Canadian (dark) birch.

A study of this great ship would be an education. in the products of the forests of the world. The following information kindly furnished by the builders would appear worthy of record on the actual utilisation of some of the above mentioned timbers.

First Class restaurant: Peroba, with feature panels in selected maple burr and Masur birch. Port. side aft private saloon, maple burr ; starboardside aft private saloon, bleached pommele, feature panel in selected maple burr. Tourist dining saloon, ash burr and grey blistered maple- sideboard, walnut. Forward and aft subsidiary stair and aft corridor promenade deck, figured ash with pillar casings and dado and doors elm burr. Midship entrance promensde deck, figured bleached mahogany with dado and doors in pommele. Two writing rooms, promenade deck, oaknut, chestnut and tables ash burr and traight grained ash and pear. Main hall and promenade deck, same timbers as writing rooms with, in addition, teak. First Class library-a beautiful roompromenade deck, oak burr and sycamore with feature panels in oak burr. Observation lounge and cockteil bar, promenade deck, maple burr with dado and horizontal bandings in cedarmah; counter front and jardinières to niche features in finely figured macassar ebony. Corridors, main hall to cocktail bar, prom. enade deck, maple burr with elm burr dado and doors. First Class children's play room, lemonwood. Sun deck, aft entrance, top and bottom course of walls in straight grained chestnut; centre course and doors in root ash; horizontal bandings in chestnut. Sun deck, forward entrance and sports deck entrance, satinee with doors and dado in elm burr. Long gallery, Betula and maple. Starboard gallery, in specially selected laurelwood. First Class smoke room-another very beautiful room-English oak 
burr, walnut and tiger oak. First Class lounge, selected maple burr with dado in makoré, walnut skirting and high and low level soffits in Masur birch. Aft and forward staircases, figured ash, dado in elm burr. Main staircase, figured ash. Dado in elm burr with feature panel on promenade deck of specially selected and cut peacock walnut burr, graded to outer sides with special elm burr. It is said that this log was specially cut for the Queen Mary. First Class ballroom, skirting and dado in specially cut logs of Makoré with small marquetry banding in the Makoré doors of maple burr ; remainder of the room painted. First Class entrance foyers on main and $B$ deck, dado in elm burr, with filling above in chestnut, banded. First Class, $A$ and $C$ decks, elm burr dado with masur birch filling banded horizontally with straight grained birch. Much of the beautiful furniture in the ship is made of Honduras and other mahogany, ook, French walnut and Austrian beech.

It is due to the modern use of veneers and ply. wood that the decoration of this vast ship in so artistic a manner has become possible. A study of the Queen Mary will be a revelation to many of the great progress which has been achieved in this direction.

\section{Educational Topics and Events}

CAMbridge.-M. T. Greig has been appointed University demonstrator in anatomy.

The Gordon Wigan Prize in chemistry has been awarded to W. C. G. Baldwin, of Christ's College, for a dissertation entitled "Phenomena associated with Optically Active Absorption Bands".

The Managers of the Balfour Fund propose to consider the appointment of a student as from October 1, 1936. The studentship is of the annual value of $£ 300$ and the appointment is for three years. Applicants need not be members of the University of Cambridge. Further information can be obtained from Prof. J. S. Gardiner, Zoological Laboratory, Cambridge, before May 31.

At Clare College, Dr. H. M. T. Taylor, University lecturer in the Faculty of Mathematics, has been elocted into an official fellowship.

OxForD.--During the visit of the British Medical Association in July, honorary degrees of D.Sc. will be conferred on Sir George Newman, Sir Cuthbert Wallace, Sir Henry Dale, Sir Walter Langdon-Brown, Dr. Robert Hutchison and Prof. Charles Singer.

H. O. Newboult and R. Opie, fellows of Magdalen College, have been appointed University lecturers in mathematics and economic science respectively. Dr. B. D. Pullinger has been appointed University lecturer and demonstrator in pathology from October l, and Dr. S. Zuckerman University lecturer and demonstrator in human anatomy from April 1, 1937.

Balliol College proposes to elect a Skynner senior student in astronomy this term. The studentship is of the value of $£ 200$ a year and may be held for two years.

Christ Church proposes to elect this term at least one 'lecturer' and one senior scholar to carry out research in science or literature. The lectureship is worth $£ 300$ a year for five years and the scholarship $£ 200$ a year for two or four years.
The subject of the course of eight lectures given this term by the Wilde lecturer in natural and comparative religion, Dr. F. L. Cross, is "Religion and Scientific Thought from the Renaissance to Leibniz".

THE mechanisation of university studies is attacked by Dr. W. S. Learned, of the Carnegie Foundation for the Advancement of Teaching, in a recently published report on the progress of the Foundation's elaborate inquiry, begun eight years ago, into the relation of secondary and higher education in Pennsylvania. The chief instrument employed in this inquiry has been an extensive series of tests covering the main aspects of general education and designed to measure the sum total of the student's acquired skills and store of serviceable knowledge-the intellectual fixed capital available for future use. The tests are said to "constitute a searching and comprehensive probe such as has never been available hitherto", and made possible comparisons of ratings of students of different academic grades and of the same student at different stages. The results expose the weaknesses of a system of grouping students according to the extent of the formal academic 'courses' they have completed. Thus : in an examina. tion of eleven thousand students belonging to three academic groups, $(a)$ high school final year, $(b)$ college second year, and $(c)$ college fourth year, 22 per cent of $(a)$ were ranked higher and 29 per cent of $(c)$ lower than the average of $(b)$, while 10 per cent of $(a)$ did better than the average of (c), and vice versa. Again, in a typical college, 34 undergraduates at the end of their first year scored higher than 72 per cent of seniors on the eve of graduation. Two years later, when the entire college was re-examined with the same test, two-thirds of these brilliant freshmen had actually lost ground. "Although as freshmen they were already beyond that intellectual level at which the college could serve them effectively, they were obliged to mark time for three more years until the calendar should release them".

\section{Science News a Century Ago}

The Dudley and Wolverhampton Coalfield

Aт a meeting of the Geological Society held on May 11, 1836, Lyell being in the chair, Murchison read a paper "On the Dudley and Wolverhampton Coalfield, and on the Formations connected with it, followed by a Description of the Lickey Quartz Rock". This was one of a series of papers in which Murchison described the structure of the border counties of England and Wales and the southern part of the Principality. The great coalfield of Dudley and Wolverhampton, the most productive in the central part of England, he said, is geologically distinguished by the total absence of the mountain limestone and the old red sandstone, which form the fundamental rocks of so many of the coal tracks of Great Britain. The formations which constitute the sub-strata of the district are known only by their irregular protrusion through the coal measures near Sedgeley and Dudley, and through the new red sandstone at Walsall, or by having been reached in some of the deepest pits. These 